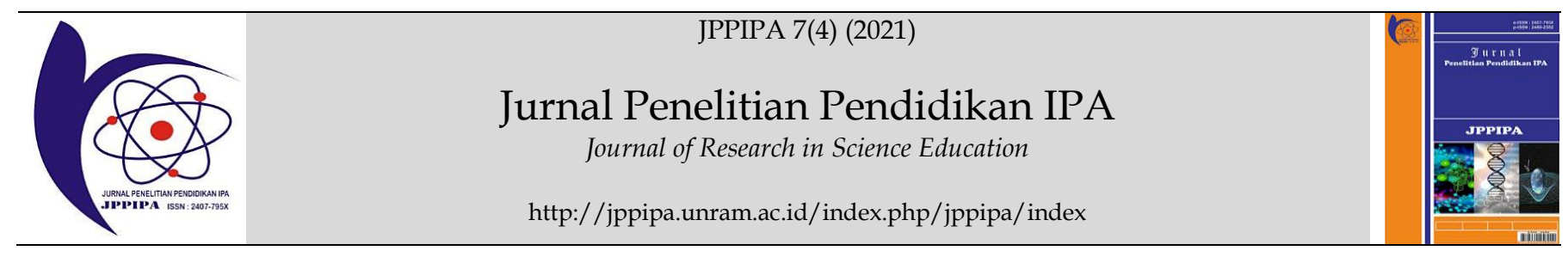

\title{
The Effectiveness of Using Student Worksheets in Science Learning on Student Learning Outcomes
}

\author{
Fajriani Chutami ${ }^{*}$, Suhartini ${ }^{2}$ \\ ${ }^{1}$ Biology Education Study Program, Postgraduate, FMIPA, Yogyakarta State University, Indonesia \\ ${ }^{2}$ Lecturer of Biology Education Study Program, Postgraduate, FMIPA, Yogyakarta State University, Indonesia
}

DOI: $\underline{10.29303 / \text { jppipa.v7i4.768 }}$

\section{Article Info}

Received: May 30th, 2021

Revised: August 24th 2021

Accepted: October $5^{\text {th }}, 2021$

\begin{abstract}
This study aims to re-analyze the effectiveness of the use of Student Worksheets in science learning on student learning outcomes. The method used in this study is a meta-analysis conducted by reviewing, summarizing, and analyzing research data from several studies that have been conducted. Previously there was a way to browse articles contained in journals that could be accessed online through Google Scholar. This metaanalysis research uses a sample of 10 relevant articles in related national journals about Student Worksheets in science learning. This meta-analysis shows that based on the calculation of the effect size, there is an effect of the use of Student Worksheets in science learning on student learning outcomes. There are two studies that have an effect size with a very high category, namely 1.336 and 1.140, three studies have an effect size with a high category, namely $0.995,0.935$, and 0.911 , and five studies that have an effect size in the medium category with a range of 0.419 to 0.735 .
\end{abstract}

Keywords: Meta-analysis; Student Worksheets; Learning Outcomes

Citation: Chutami, F., \& Suhartini, S. (2021). The Effectiveness of Using Student Worksheets in Science Learning on Student Learning Outcomes. Jurnal Penelitian Pendidikan IPA, 7(4), 587-592. doi:https://doi.org/10.29303/jppipa.v7i4.768

\section{Introduction}

Learning is an effort or activity designed to help someone learn new abilities and values (Arsyad, 2013). Learning is an interactive process between educators and students in a learning environment to achieve learning objectives. The learning process is an activity that is inseparable from human life. The task of educators is to deliver learning materials to students through communication interactions in the learning process. The most important thing in learning is the learning process.

Natural science is the study of the universe and its contents and the events that occur in it, which experts developed through a series of scientific processes (Sujana, 2014). Learning science is divided into two disciplines, namely mathematics and science.
The natural science cluster is divided into three fields, namely the fields of biology, chemistry, and physics (Darmawan et al., 2021).

The science learning process emphasizes providing direct experience to develop competencies to explore and understand the natural surroundings scientifically and then be directed to practice so that it will help students gain deeper experience and understanding. Three components in science learning include facts, concepts, and procedures (Wilujeng, 2018).

Teachers can do fun learning by applying various approaches, strategies, models, and learning media or appropriate teaching materials (Nurul \& Paidi, 2020). The development of teaching materials is important in improving the quality of learning so that students can better understand the material being 
studied and in order to achieve the learning process. Panggabean (2020) explains that teaching materials are all forms of materials, information, tools, and texts that are used to assist teachers in carrying out teaching and learning activities.

Teaching materials are systematic, meaning that they are arranged in order to make it easier for students to learn. Teaching materials are one of the components that must exist because teaching materials are something that will be studied, observed, studied, and used as a material that students will master (Ramdoniati et al., 2018).

The student worksheet is a worksheet for students to solve the problems contained in the book, and the teacher gives it at each meeting. The Student Worksheet includes a set of essential activities that students must carry out to maximize understanding in an effort to form basic abilities according to indicators of achievement of learning outcomes that must be achieved (Parenta, 2020).

Student worksheets are one of the means to assist and facilitate teaching and learning activities so that effective interactions will be formed between students and teachers and can increase student activities in improving learning achievement (Zubainur \& Bambang, 2017).

Based on this opinion, it can be concluded that the student worksheet is one of the means to assist students in the learning process. The Student Worksheet contains activities that students must carry out according to the indicators of achievement of learning outcomes that must be achieved so as to improve student learning achievement.

The function of the Student Worksheet for teachers is so that students can learn according to their respective learning speeds, and the subject matter can be designed in such a way that it can meet the needs of students. By using Student Worksheets, teaching and learning activities can be more effective and efficient because there are already student assignment sheets that have been systematically arranged according to the essential competencies they must achieve (Khasanah \& Fadila, 2018).

Student Worksheets can train students to be active and independent, make it easier for them to understand the material, be concise, contain assignments for practice, and be suitable for use. The use of Student Worksheets in the learning process can help students understand the material being taught and raise students' scientific attitudes (Yulianti, 2016).

The use of suitable teaching materials such as Student Worksheets is expected to improve student learning outcomes. According to Wahyuningsih (2020), learning outcomes include cognitive, affective, and psychomotor aspects that can reflect the quality of one activity in the learning process. Khairini et al. (2021) said that learning focuses on knowledge and learning activities to develop students' attitudes, knowledge, and skills.

In this meta-analysis, a study was conducted on research articles discussing the use of Student Worksheets in science learning in the last ten years that were published in national journals with ISSN. The purpose of this study is to re-analyze the effectiveness of the use of Student Worksheets in science learning on student learning outcomes.

\section{Method}

The type of research used in this research is meta-analysis. Meta-analysis is research conducted by reviewing, summarizing, and analyzing research data from several pre-existing studies by browsing articles in journals that can be accessed online through Google Scholar. This meta-analysis research uses a sample of 10 relevant articles in related national journals about Student Worksheets in science learning. The keywords used by the researcher in searching the articles are student worksheet, science student worksheet, and student learning outcomes.

The effectiveness of the use of Student Worksheets in science learning on student learning outcomes is carried out by calculating the effect size using the Glass formula (Glass, et al, 1981) with the following criteria:

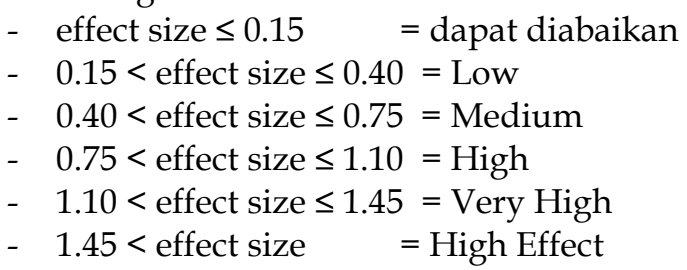

\section{Result and Discussion}

The data used in this study is still extensive, so that the data is processed by summarizing and extracting its essence. This study used a sample of 10 articles in national journals about the use of Student Worksheets in science learning in the last ten years (2011-2021). The distribution of the sample articles can be seen in Table 1. 
Table 1. Article Sample

\begin{tabular}{lllcc}
\hline No & Codes & Researcher & Years & Knowledge Field \\
\hline 1 & A1 & Ananda, Hufri, \& Nurhayati & 2016 & Physics \\
2 & A2 & Mustika, Saptaningrum, \& Susilawati & 2016 & Physics \\
3 & A3 & Lestari, Anwar, \& Madang & 2017 & Biology \\
4 & A4 & Amalia, Hasri, \& Sulastry & 2018 & Chemistry \\
5 & A5 & Rahmi, Darvina, Masril, \& Hidayati & 2019 & Physics \\
6 & A6 & Oktricia, Yani, \& Ansori & 2019 & Biology \\
7 & A7 & Listari, Yani, \& Yennita & 2019 & Biology \\
8 & A8 & Erina & 2019 & Physics \\
9 & A9 & Aryanto, Yeni, \& Marlina & 2020 & Biology \\
10 & A10 & Bulu, Dharmadewi, Suryatini, \& Wiadnyana & 2021 & Biology \\
\hline
\end{tabular}

Articles about the effectiveness of Student Worksheets in science learning that were selected in this meta-analysis were one type of development research. Ten studies were experimental studies that tested the effectiveness of Student Worksheets in science learning. This type of experimental research is widely used because it allows researchers to produce appropriate teaching materials based on expert judgment and to find out the effectiveness of the media developed in classroom learning.

Tabel 2. Effect Size

\begin{tabular}{llll}
\hline No & Codes & Effect Size Values & Descriptions \\
\hline 1 & A10 & 1.336 & Very High \\
2 & A2 & 1.140 & \\
3 & A3 & 0.995 & High \\
4 & A4 & 0.935 & \\
5 & A7 & 0.911 & Medium \\
6 & A8 & 0.735 & \\
7 & A9 & 0.665 & \\
8 & A5 & 0.617 & \\
9 & A6 & 0.512 & \\
10 & A1 & 0.419 & \\
\hline
\end{tabular}

Effect size is an essential component in the metaanalysis used to summarize the results of the studies in the meta-analysis. Effect size shows the magnitude of the relationship between variables in each study. Based on the calculation of the effect size in table 2, the effect of the Student Worksheet on science learning on student learning outcomes can be seen from these results. Two studies have an effect size with a very high category, namely 1.336 and 1.140, three studies have an effect size with a high category, namely $0.995,0.935$, and 0.911, and five studies that have an effect size in the medium category with a range of 0.419 to 0.735 .

From the results obtained, there is no effect size that is included in the low category, so it can be concluded that the use of Student Worksheets in science learning is very influential on student learning outcomes. Overall, from the results of research that has been done, the use of Student Worksheets in science learning positively affects student learning outcomes.
This is supported by (Ranti \& Usmeldi, 2019:8), which states that the Integrated Science Student Worksheet effectively improves student competencies assessed from three competencies: attitude competence, knowledge competence, and skill competence. The same thing was also expressed by (Amalia et al., 2018) based on the results of research and discussions carried out. It can be concluded that the use of Student Worksheets affects critical thinking skills and student learning outcomes.

Table 3. Effect Size of the Effectiveness of Using Student Worksheets in Science Learning on Learning Outcomes based on Education Level

\begin{tabular}{lllll}
\hline No & $\begin{array}{l}\text { level of } \\
\text { education }\end{array}$ & Frequency & $\begin{array}{l}\text { Frequency } \\
\text { Relative }(\%)\end{array}$ & $\begin{array}{l}\text { Effect } \\
\text { Size }\end{array}$ \\
\hline 1 & SMP/MTs & 3 & 30 & 0.772 \\
2 & SMA/MA/SMK & 7 & 70 & 0.850 \\
\hline
\end{tabular}

Table 3 shows the distribution of research on the use of Student Worksheets in science learning by education level. Based on the results in Table 2, it can be seen that research on the use of Student Worksheets in science learning was mostly carried out at the SMA/MA/SMK level as many as seven articles with a relative frequency of $70 \%$ and an effect size of 0.850 in the high category. Furthermore, there are three articles at the SMP/MTs level with a relative frequency of $30 \%$ and an effect size of 0.772, which is in the high category.

Table 4. Effect Size of the Effectiveness of Using Student Worksheets in Science Learning on Learning Outcomes by Field of Science

\begin{tabular}{lllll}
\hline \multirow{2}{*}{ No } & $\begin{array}{l}\text { Knowledge } \\
\text { Field }\end{array}$ & Frequency & $\begin{array}{l}\text { Frequency } \\
\text { Relatif }(\%)\end{array}$ & $\begin{array}{l}\text { Effect } \\
\text { Size }\end{array}$ \\
\hline 1 & Biology & 5 & 50 & 0.884 \\
2 & Chemistry & 1 & 10 & 0.935 \\
3 & Physics & 4 & 40 & 0.728 \\
\hline
\end{tabular}

Table 4 shows the Effect Size of the Effectiveness of Student Worksheets on Science Learning on Learning Outcomes by Field of Science. In the field of biology, there are five articles, and an effect size of 
0.884 is obtained, which is included in the high category. In the field of chemistry, there is one effect size of 0.935 is obtained, which is included in the high category. There are four articles in the field of physics, and an effect size of 0.728 is obtained, which is included in the medium category.

Based on the results obtained from the research in the ten articles, learning science using Student Worksheets can improve student learning outcomes as seen from learning outcomes that increase after using Student Worksheets, although the learning outcomes obtained from each study are different.

This can be influenced by various factors, both internal and external factors. (Wahyuningsih, 2020) explained that many factors influence student learning outcomes because humans in achieving learning outcomes involve physical activity and brain activity. Internal factors are factors that exist within students that influence learning outcomes.

These internal factors are intelligence factors (skills), interest and motivation factors, learning methods that include a concentration in learning, efforts to relearn the material that has been studied, read carefully and try to master well, always try to solve and practice working on problems. Besides being influenced by internal factors, student learning outcomes are also influenced by external factors, including family, school, and community factors.

Some examples of Student Worksheets in science learning can be seen in the following picture.
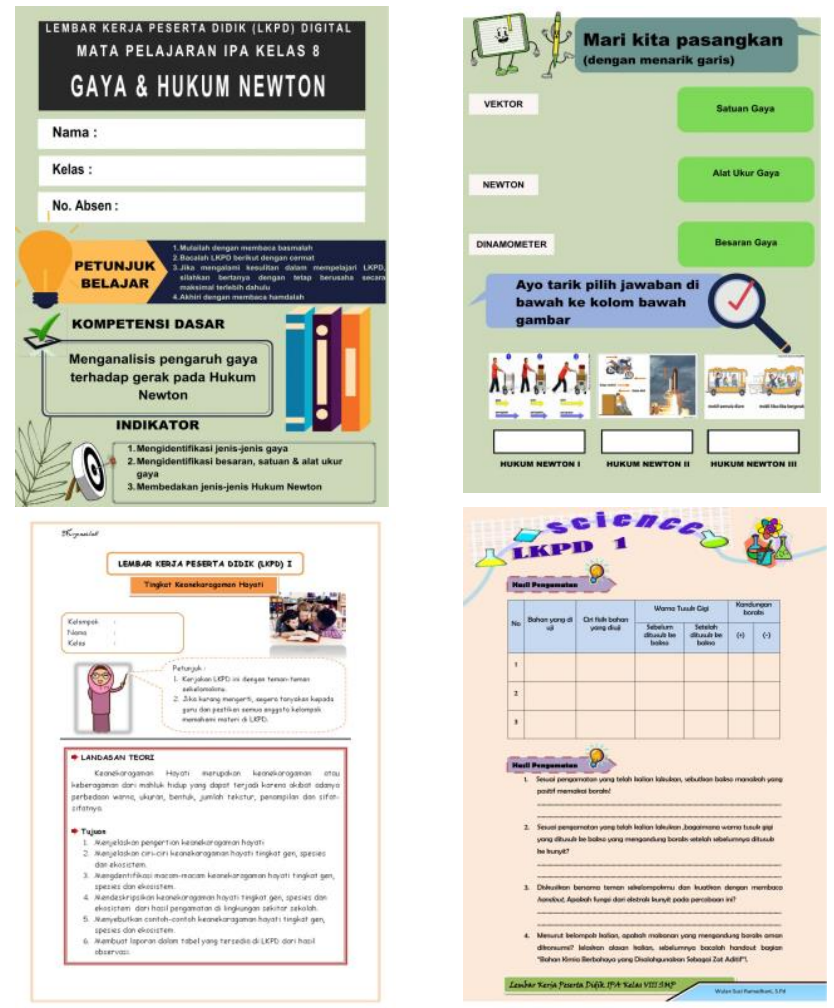

Figure 1. Examples of Student Worksheets

\section{Conclusion}

From the results of the meta-analysis that has been carried out regarding the effectiveness of the use of Student Worksheets in science learning, it can be concluded that based on the calculation of effect size, there is an effect of using Student Worksheets in science learning on student learning outcomes. There are two studies that have an effect size with a very high category, namely 1.336 and 1.140, three studies have an effect size with a high category, namely 0.995, 0.935, and 0.911 , and five studies that have an effect size in the medium category with a range of 0.419 to 0.735 .

\section{References}

Amalia, Hasri, \& Sulastry, T. (2018). Pengaruh penggunaan lkpd terhadap keterampilan berpikir kritis dan hasil belajar peserta didik kelas XI IPA SMA negeri 6 maros (studi materi pokok hidrolisis garam). Chemistry Education Review (CER), 2(1), 1-9. doi: https://doi.org/10.26858/cer.v0i0.7454 [Indonesian]

Ananda, N. R., Hufri, \& Nurhayati. (2016). Pengaruh penerapan LKS bernuansa keterampilan berpikir kritis dalam pendekatan saintifik terhadap hasil belajar fisika siswa kelas X SMA N 2 padang. Pillar Of Physics Education, 7(April), 41-48. doi: http://dx.doi.org/10.24036/1988171074 [Indonesian]

Arsyad, A. (2013). Media Pembelajaran. Jakarta: Rajagrafindo Persada. [Indonesian]

Aryanto, A., Yeni, L. F., \& Marlina, R. (2020). Efektivitas Creative Problem Solving Disertai LKS Terhadap Hasil Belajar Dan Motivasi Kelas VII SMPN. Jurnal Edukasi Matematika Dan Sains, 8(2), 96. doi: https://doi.org/10.25273/jems.v8i2.6121 [Indonesian]

Bulu, M., Dharmadewi, A. A. I. M., Suryatini, K. Y., \& Wiadnyana, I. G. A. G. (2021). Pengaruh model pembelajaran auditory intellectually repetition (AIR) berbantuan LKPD terhadap motivasi dan hasil belajar biologi peserta didik kelas X MIA SMA Negeri 5 Denpasar Tahun Pelajaran 2019/2020. Jurnal Emasains: Jurnal Edukasi Matematika Dan Sains, X(1). doi: https://doi.org/10.5281/zenodo.4732982 [Indonesian]

Darmawan, E., Yusnaeni, Ismirawati, N., \& Ristanto, R. H. (2021). Strategi Belajar Mnegajar Biologi. Magelang: Pustaka Rumah Cinta. [Indonesian]

Erina, R. (2019). Pengaruh Model Advance Pokok Pengukuran Di Kelas X SMK Swasta Budi Setia Sunggal. Jurnal Penelitian Fisikawan, 2(2012), 7-13. 
Retrieved from

http://jurnal.darmaagung.ac.id/i......view/63 [Indonesian]

Khairini, K., Khaldun, I., \& Pada, A. U. T. (2021). The Effect of Student Worksheets Through the Edmodo Network on Concept Understanding and Independent Learning on Hydrocarbon Materials. Jurnal Penelitian Pendidikan IPA, 7(3), 429. doi: https://doi.org/10.29303/ippipa.v7i3.701

Khasanah, B. A., \& Fadila, A. (2018). Pengembangan Lkpd Geometri Transformasi Dengan Motif Tapis Lampung. JURNAL E-DuMath, 4(2), 59. doi: https://doi.org/10.26638/je.734.2064

[Indonesian]

Lestari, Y., Anwar, Y., \& Madang, K. (2019). Pengaruh Penerapan Model Pembelajaran Learning Cycle 7E Berbantuan LKPD terhadap Pemahaman Konsep Peserta Didik pada Materi Sistem Sirkulasi Manusia untuk Kelas XI SMA Negeri 1 Indralaya. Jurnal Pembelajaran Biologi: Kajian Biologi dan Pembelajarannya, 4(2), 216-225. doi:https://doi.org/10.36706/fpbio.v4i2.7124.

[Indonesian]

Listari, M. D., Yani, A. P., \& Yennita, Y. (2019). Implementasi LKPD Berdasarkan Eksplorasi Tanaman Obat Suku Pekal Di SMA 8 Kota Bengkulu. Diklabio: Jurnal Pendidikan Dan Pembelajaran Biologi, 3(1), 49-58. doi: https://doi.org/10.33369/diklabio.3.1.49-58 [Indonesian]

Mustika, M., Saptaningrum, E., \& Susilawati, S. (2016). Pengaruh Penggunaan LKS dengan Pendekatan Saintifik pada Materi Objek IPA dan Pengamatannya terhadap Hasil Belajar IPA Kelas VII MTs Negeri 1 Semarang. Jurnal Penelitian Pembelajaran Fisika, 7(1), 63-71. doi: https://doi.org/10.26877/ip2f.v7i1.1154

[Indonesian]

Nurul, A., \& Paidi. (2020). The Effectiveness of SAVI Approach with Macromedia Flash Toward SStudents'Critical Thinking Ability. Advances in Social Science, Education and Humanities Research, 397(19), 1031-1037. doi: https://doi.org/10.2991/assehr.k.200129.127

Oktricia, H., Yani, A. P., \& Ansori, I. (2019). Pengaruh Penerapan LKPD Identifikasi Jenis-Jenis Bambu Terhadap Hasil Belajar Peserta Didik. Diklabio: Jurnal Pendidikan Dan Pembelajaran Biologi, 3(2), 166-173. doi:

https://doi.org/10.33369/diklabio.3.2.166-173 [Indonesian]

Panggabean, N. H. (2020). Desain Pengembangan Bahan Ajar Berbasis Sains. Medan: Yayasan Kita Menulis. [Indonesian]

Parenta. (2020). Model Pembelajaran Advance Organizer
Collaboration. Sulawesi Selatan: Aksara Timur. [Indonesian]

Rahmi, F., Darvina, Y., Masril, \& Hidayati. (2019). Dampak Penerapan LKS Virtual Laboratorium Terintegrasi Pendekatan Saintifik Pada Materi Fluida Statis Dan Dinamis Di Kelas XI. Pillar Of Physics Education, 12(2), 241-248. doi: http://dx.doi.org/10.24036/4785171074 [Indonesian]

Ramdoniati, N., Muntari, M., \& Hadisaputra, S. (2018). Pengembangan Bahan Ajar Kimia Berbasis Problem Based Learning untuk Meningkatkan Keterampilan Metakognisi. Jurnal Penelitian Pendidikan IPA, 5(1). doi:https:// doi.org/10.29303/jppipa.v5i1.148 [Indonesian]

Ranti, S., \& Usmeldi. (2019). Development of integrated science sstudent'sworksheet (LKPD) based on research-based learning integrated with religion value. Journal of Physics: Conference Series, 1185(1). doi: $\quad$ https://doi.org/10.1088/17426596/1185/1/012143

Sujana, A. (2014). Dasar-Dasar IPA: Konsep dan Aplikasinya. Bandung: UPI Press. [Indonesian]

Wahyuningsih, E. S. (2020). Model Pembelajaran Mastery Learning Upaya Peningkatan Keaktifan dan Hasil Belajar Siswa. Yogyakarta: Deepublish. [Indonesian]

Wilujeng, I. (2018). IPA Terintegrasi dan Pembelajarannya. Yogyakarta: UNY Press. [Indonesian]

Yulianti, D. (2016). Problem-Based Learning Model Used to Scientific Approach Based Worksheet for Physics to Develop Senior High School Students Characters. Journal of Physics: Conference Series, 755(1), 4-9. doi: https://doi.org/10.1088/17426596/755/1/011001

Zikrullah, M., Wildan, \& Andayani, Y. (2017). Pengembangan Lembar Kegiatan Siswa (Lks) Model Learning Cycle 5E. Jurnal Penelitian Pendidikan IPA, 2(2). doi: https://doi.org/10.29303/jppipa.v2i2.40 [Indonesian]

Zubainur, C. M., \& Bambang, R. M. (2017). Perencanaan Pembelajaran Matematika. Banda Aceh: Syiah Kuala University Press. [Indonesian] 